\title{
Corrigendum: Does mosquito control by Bti spraying affect the phytoplankton community? A 5-year study in Camargue temporary wetlands (France)
}

\author{
Stéphanie Fayolle ${ }^{1 *}$, Céline Bertrand ${ }^{1}$, Maxime Logez ${ }^{1}$ and Evelyne Franquet ${ }^{1}$ \\ Aix-Marseille Université, Institut Méditerranéen de Biodiversité et d'Ecologie Marine et Continentale (IMBE) UMR CNRS/IRD/ \\ Avignon Université, FST St-Jérome, case 421, 13397 Marseille Cedex 20, France
}

Received 25 October 2015; Accepted 25 October 2015

This article is a corrigendum of a former version by Fayolle et al., originally published in Ann. Limnol. - Int. J. Lim. 51: 189-198, 2015. In its original form, the article contained portions of text that were identical to Duguma et al., J. Appl. Ecol. 52: 763-773, 2015, similarities that were not detected by our plagiarism detection software upon initial submission of Fayolle et al.'s manuscript. Based on independent investigations, the Editors of Ann. Limnol. - Int. J. Lim. and J. Appl. Ecol. established that Duguma et al.'s words found in Fayolle et al. were suggested to the latter authors during the review process (without citing any source), so that Fayolle et al. unintentionally reproduced sentences by Duguma et al. in their revised manuscript. After due consideration, authors and Editors concluded that a retractation of Fayolle et al. was not appropriate. The Editors of Ann. Limnol. - Int. J. Lim. have asked Fayolle et al. to prepare a corrigendum by rewriting those parts of the text that are identical to Duguma et al., and referencing the article in J. Appl. Ecol. Where Ann. Limnol. - Int. J. Lim. is concerned, plagiarism check remains a common practice at the time of first submission, but we will now systematically check revised manuscripts as well. Last, we wish to thank the authors of both articles as well as the Editor of $J$. Appl. Ecol. for helping us sorting out a very difficult situation.

The Editors

\begin{abstract}
Mosquitoes are both vectors of disease and a hindrance to outdoor activities. Since its discovery in 1976, the larvicide Bacillus thuringiensis var. israelensis (Bti) has proven its effectiveness in controlling mosquito populations, with negligible environmental impact. We performed an integrated, 5-year study of the direct and indirect effects of Bacillus thuringiensis var. israelensis (Bti applied as VectoBac ${ }^{\circledR}$ WG) on phytoplankton communities in the Camargue temporary wetlands of the French Mediterranean coast. Mosquito larvae are considered major algae predators, so a significant reduction in mosquito larval density $(>80 \%)$ in natural wetlands due to $B t i$ treatment could indirectly affect phytoplankton communities. Physical parameters and phytoplankton were sampled in the water of three temporary oligohaline pools between 2006 and 2011 in the following order: $\mathrm{T} 0=1$ day before treatment (control), $\mathrm{T} 2=2$ days after treatment, $\mathrm{T} 5=5$ days after treatment, T11=11 days after treatment. We found no negative effects of Bti treatments on total phytoplankton density and community diversity (Shannon's entropy and Pielou's evenness). However, we observed changes in the density of some taxonomic groups; Diatoms were replaced by drought-resistant algae typical of temporary wetlands. These results suggest that changes in phytoplankton community structure are largely driven by natural environmental factors and by the ecological complexity of these temporary wetlands.
\end{abstract}

Key words: Bacillus thuringiensis / environmental management / food webs / mosquito control / wetlands

\footnotetext{
*Corresponding author: stephanie.fayolle@univ-amu. fr
} 


\section{Introduction}

Bacillus thuringiensis var. israelensis serotype H14 (Bti) is a biological larvicide increasingly used worldwide for selective control of larval mosquito populations (Lacoursière and Boisvert, 2004; Becker, 2006; Wegner, 2006; Östman et al., 2008; Després et al., 2011). This bacterial larvicide is applied via aerial spraying over large areas in Northeastern Spain, along the French Mediterranean coast (Duchet et al., 2010) and also in the French Atlantic coastal wetlands (Caquet et al., 2011; Lagadic et al., 2014). All these regions contain temporary aquatic ecosystems, habitats propitious to the massive emergence of mosquitoes with major nuisance potential (Becker et al., 2003; Duchet et al., 2010; Lagadic et al., 2014). Living near wetlands often entails serious health hazards for humans and animals due to increased risk of mosquito-borne diseases (Russell, 1999; Walton, 2002; Kirkman et al., 2011; Lagadic et al., 2014). To date, $B t i$ represents the best alternative to chemical insecticides for mosquito control (Després et al., 2011) and is described as non-toxic to humans, mammals, birds, fish, plants and most aquatic organisms (Boisvert and Boisvert, 2000; Lacey and Merritt, 2004). Bti is the only larvicide used in Europe following implementation of the EU Biocidal Products Directive 98/8/EC (Lagadic et al., 2014). Findings from numerous studies indicate that Bti can be considered as a larvicide with low environmental toxicity, even when used in repeated treatments from 3 to 7 years. Most of these long-term studies were conducted on invertebrate populations, under the assumption of direct effects. In a 4-year study (1998-2001) by Lagadic et al. (2002) in Morbihan, France, the health, number and abundance of non-target aquatic invertebrates present in mosquito breeding sites treated annually with Bti (VectoBac ${ }^{\circledR} 12 \mathrm{AS}$ ) were monitored. The authors found that the two sentinel species Nereis diversicolor and Chironomus salinarius were not impacted by long-term Bti-treatment, and that environmental fluctuations had greater influence on community structure than Bti. Other short- to long-term field studies (Caquet et al., 2011; Lagadic et al., 2014) aimed at analyzing the effects of $B t i$-treatments on non-target aquatic invertebrates in wetlands. These studies concluded that changes in invertebrate communities in terms of taxonomic richness and/or species abundance were mostly driven by spatial-seasonal changes in natural environmental parameters, rather than by Bti-treatments (see also Hershey et al., 1998; Russell et al., 2009). In summary, no study was able to reveal $B t i$-induced alterations of invertebrate community structure. Bti application at recommended rates (relative to the operational scale) further support the absence of adverse effects on non-target invertebrates and vertebrates living in the same habitats as mosquito larvae (Lacoursière and Boisvert, 2004; Lacey and Merritt, 2004; Després et al., 2011; Lagadic et al., 2014).

The Camargue temporary wetlands are ecological niches favorable to the development of mosquito species. Each Bti-treatment causes almost an $80 \%$ mortality of phytophagous mosquito larvae, with indirect effects on the microorganisms. For instance, Östman et al. (2008) demonstrated that a strong reduction in mosquito larvae density by $B t i$ treatments in temporary flooded wetlands indirectly affected the protozoan community through predation release (4.5 times increase in protozoan density). $\mathrm{Xu}$ et al. (2008) observed an increase in the density of Flavobacterium species in tree holes after the eradication of Aedes triseriatus larvae by Bti treatment. These studies demonstrate that the local extinction of mosquito larvae by Bti treatments causes shifts in microbial communities, because there is a "top-down" control of food resource by the filter-feeding larvae. Other types of indirect effects are documented. Duguma et al. (2015) suggested that the inhibition of algal growth in aquatic microcosms treated with high Bti concentrations was associated with both the elimination of some bacterial taxa and the increase of bacterial diversity. $\mathrm{Su}$ and Mulla (1999) found that Bti applications in microcosms suppressed photosynthesis and algal productivity, and decreased the abundance of two unicellular green-algae. Accordingly, lower water turbidity was observed in the treated microcosms than in the control ones. These results suggest that, in addition to predation release (elimination of mosquito larvae), Bti can alter algal communities through complex interactions within the microbial communities.

Phytoplanktonic algae make a significant contribution to primary production and nutrient cycling in wetlands (Goldsborough and Robinson, 1996; Robinson et al., 1997; Wu and Mitsch, 1998; Weilhoefer and Pan, 2007; Hagen, 2009). Phytoplankton cells are also a significant dietary resource for larvae of many species mosquito that feed opportunistically on microorganisms (i.e., bacteria, fungal, protozoa, algae) (Merritt et al., 1992). The algae include phytoplankton filtered from the water column, periphyton grazed from the surface of various substrate types, or from the bottom of the pools. Gut content analyses of a variety of mosquito larvae showed that algae are well represented in proportion to their abundance among the microflora where mosquito larvae feed (Marten, 2007).

In this study, we monitored the effects of Bti treatment on the phytoplankton of wetlands, seeking to determine whether mosquito control could induce modifications in food web structure. The effects were tested on total phytoplankton density, on the density of different phytoplankton taxonomic groups, and on community structure (diversity and evenness). Phytoplankton might be subject either to direct toxic effects, or to indirect effects linked to decreased grazing pressure from mosquito larvae. Our hypothesis was that any decrease in mosquito larvae population would induce phytoplankton proliferation in our wetlands immediately after Bti treatment.

\section{Materials and methods}

\section{Study sites}

The French Mediterranean coast includes a large number of temporary wetlands characterized by large 
Table 1. Causes of flooding, and sampling chronology before and after Bti-treatment (T0 = 1 day before treatment and considered as control - T2, T5 and T11, respectively, 2, 5 and 11 days after treatment) at three sites: Clos d'Armand = site 1; Belugue = site 2; Mourgues $=$ site 3 .

\begin{tabular}{|c|c|c|c|c|c|c|}
\hline \multirow{3}{*}{$\frac{\text { Wetland }}{\text { Site } 1}$} & \multirow[b]{2}{*}{ Sampling campaign } & \multirow[b]{2}{*}{ Cause of flooding } & \multirow[b]{2}{*}{ T0 Control } & $\mathrm{T} 2$ & T5 & T11 \\
\hline & & & & \multicolumn{3}{|c|}{ Post-treatment dates } \\
\hline & August 2006 & Irrigation & + & + & + & Dried \\
\hline \multirow{7}{*}{ Site 1} & September 2006 & Precipitation & + & + & + & + \\
\hline & May 2008 & Irrigation + precipitation & + & + & + & + \\
\hline & August 2008 & Irrigation & + & + & + & + \\
\hline & June 2009 & Irrigation & + & + & + & + \\
\hline & September 2009 & Precipitation & + & + & + & + \\
\hline & April 2010 & Precipitation & + & + & + & Dried \\
\hline & May 2010 & Irrigation & + & + & + & + \\
\hline \multirow[t]{6}{*}{ Site 2} & May 2007 & Irrigation & + & + & + & + \\
\hline & June 2008 & Irrigation & + & + & + & Dried \\
\hline & May 2009 & Irrigation + precipitation & + & + & + & + \\
\hline & July 2010 & Irrigation & + & + & + & Dried \\
\hline & April 2011 & Irrigation + precipitation & + & + & + & + \\
\hline & June 2011 & Precipitation & + & + & + & + \\
\hline \multirow[t]{5}{*}{ Site 3} & February 2010 & Precipitation & + & + & + & + \\
\hline & May 2010 & Precipitation & + & + & + & Dried \\
\hline & September 2010 & Precipitation & + & + & Dried & Dried \\
\hline & April 2011 & Precipitation & + & + & + & + \\
\hline & July 2011 & Precipitation & + & + & + & + \\
\hline
\end{tabular}

spatial and temporal variations in many environmental parameters (Nuccio et al., 2003). The Camargue Rhone Delta region contains a great variety of natural and human-modified ecosystems, including temporary ponds and agricultural fields. The hydrological cycle of these ecosystems results both from autumnal precipitation and artificial irrigation (rice-growing), inducing an alternating flooding/drought cycle. To reduce mosquito nuisance, an experimental control program encompassing 2500 of the 25000 ha of potential larval biotopes was assessed through impact studies on the non-target flora and fauna by Parc Naturel Régional de Camargue (Poulin et al., 2010). This mosquito larva control has systematically been carried out since 2006 by aerial spraying of Bti (aqueous solution of VectoBac ${ }^{\circledR} 12 \mathrm{AS}$ at $2.5 \mathrm{~L}^{\mathrm{h}} \mathrm{ha}^{-1}$ ). Expressed as International Toxic Units (ITU), the recommended application rate of VectoBac ${ }^{\circledR}$ 12AS $\left(0.371 \times 10^{9}-1.59 \times 10^{9}\right.$ ITU.ha $^{-1}$ corresponding to 0.29-1.24 L.ha $\left.{ }^{-1}\right)$.

The study investigated three shallow Mediterranean temporary oligohaline wetlands located in Southern France (Clos d'Armand = site $1\left(43^{\circ} 21^{\prime} 56^{\prime \prime} \mathrm{N}\right.$; $\left.4^{\circ} 48^{\prime} 59^{\prime \prime} \mathrm{E}\right)$, Belugue $=$ site $2\left(43^{\circ} 25^{\prime} 27^{\prime \prime} \mathrm{N} ; 4^{\circ} 40^{\prime} 35^{\prime \prime} \mathrm{E}\right)$ and Mourgues = site $\left.3\left(43^{\circ} 30^{\prime} 16^{\prime \prime} \mathrm{N} ; 4^{\circ} 16^{\prime} 04^{\prime \prime} \mathrm{E}\right)\right)$. All three sites were located in areas treated in winter, spring and summer after flooding by precipitation or irrigation. Treatments of the wetlands were performed by technicians from the "Entente Interdépartementale pour la démoustication du littoral méditerranéen" (EID méditerranée $=$ French public organization responsible for mosquito control and survey in Southern France).

\section{Phytoplankton community and physico-chemical parameters}

Analysis of phytoplankton dynamics was conducted over 19 campaigns spread over 5 years. For each campaign, total phytoplankton densities, densities of different phytoplankton taxonomical groups and community structure were analyzed before and after each treatment in the following order: $\mathrm{T} 0=$ one day before treatment and considered as control, T2, T5 and T11 = 2, 5 and 11 days, respectively, after the treatment. Samples at T11 were not systematically taken due to drying out of the wetlands (Table 1).

In the wetlands where phytoplankton was sampled, water depth was measured to the nearest millimeter using a graduated aluminum gauge at the same point on every sampling date. Concurrently, water temperature, conductivity and salinity were measured at $5 \mathrm{~cm}$ below the water surface, using a portable probe (WissenschaftlichTechnische-Werkstatten - WTW). Measurements were always made between 9:00 a.m. and 12:00 noon to ensure consistency among data relative to possible circadial influence.

Nitrites $\left(\mathrm{N}-\mathrm{NO}^{-2}\right)$, nitrates $\left(\mathrm{N}-\mathrm{NO}^{-3}\right)$ and soluble reactive phosphate (SRP) were measured at the beginning of each campaign (control T0), because these parameters play a key role in eutrophication of surface waters (OECD, 1982; Reavie et al., 1995). High P concentrations have been linked to increasing rates of plant growth, changes in species composition and proliferation of planktonic and epiphytic and epibenthic algae, resulting 
Table 2. Values and range of variation (minimum to maximum) of environmental parameters measured in water for the three wetlands from 2006 to 2011. (Site $1 n=30$; Site $2 n=22$; Site $3 n=15$ ). SRP are soluble reactive phosphate.

\begin{tabular}{|c|c|c|c|c|c|c|c|}
\hline Wetlands & & $\mathrm{T}\left({ }^{\circ} \mathrm{C}\right)$ & Depth $(\mathrm{cm})$ & Salinity (g.L $\mathrm{L}^{-1}$ ) & $\mathrm{N}-\mathrm{NO}^{-2}\left(\mathrm{mg}^{-\mathrm{L}^{-1}}\right)$ & $\mathrm{N}-\mathrm{NO}^{-3}\left(\mathrm{mg} . \mathrm{L}^{-1}\right)$ & SRP $(\mu g . \mathrm{L}$ \\
\hline \multirow[t]{3}{*}{ Site 1} & Mean & 21.1 & 28 & 2.3 & $<0.01$ & $<0.1$ & $<0.01$ \\
\hline & Min & 16.3 & 5 & 0.4 & $<0.01$ & $<0.1$ & $<0.01$ \\
\hline & Max & 23.1 & 47 & 3.1 & $<0.01$ & $<0.1$ & 0.01 \\
\hline \multirow[t]{4}{*}{ Site 2} & Mean & 21.3 & 35 & 1.7 & $<0.01$ & 0 & $<0.01$ \\
\hline & Min & 17.4 & 6 & 0.1 & $<0.01$ & 0 & $<0.01$ \\
\hline & $\operatorname{Max}$ & 25.2 & 56 & 2.5 & $<0.01$ & $<0.1$ & 0.04 \\
\hline & Mean & 17.8 & 30 & 2.1 & $<0.01$ & 0 & $<0.01$ \\
\hline \multirow[t]{2}{*}{ Site 3} & Min & 9.4 & 7 & 0.6 & $<0.01$ & 0 & $<0.01$ \\
\hline & $\operatorname{Max}$ & 25.9 & 43 & 3.7 & $<0.01$ & $<0.1$ & 0.01 \\
\hline
\end{tabular}

in shading of higher plants (Mainstone and Parr, 2002). Nitrites and nitrates were analyzed from water samples filtered in the laboratory using Whatman GF/C glass-fiber filters according to APHA (1989). SRP, a measure of monomeric inorganic phosphorus (orthophosphate) in solution, was measured spectrophotometrically following the formation of phosphomolybdic acid.

For each date and site, three phytoplankton samples (pseudo-replicates) were realized, making a total of 12 samples per mosquito control campaign. Three water samples were collected using PVC sterile $1 \mathrm{~L}$ bottles at the water sub-surface. These three phytoplankton samples were taken at points far enough apart to represent the entire wetland surface. All in all, 205 phytoplankton samples were preserved with formaldehyde solution $(35 \%)$. Under an "Olympus" inverted microscope $(\times 400$ magnification), phytoplankton taxa were identified and the number of cells were counted for each species, allowing densities to be estimated for each species. Quantification of phytoplankton total cell number (density) was provided via standard counting techniques (APHA, 1989). Digested Bacillariophyta samples were mounted in a highly refractive medium, Naphrax, accentuating the frustular details used in taxonomy. Most taxa were identified using the diverse band of the Süsswasserflora von Mitteleuropa (Krammer and Lange-Bertalot, 1986, 1988, 1991a, 1991b; Komàrek and Anagnostidis, 1999, 2005). Euglenophyta was identified using the atlas of Wotowski and Hindàk (2005).

\section{Statistical analysis}

For each site and campaign, between-campaigns $(n=19)$ and between-dates comparisons were analyzed for total density values measured at T0 (control) and at T2, T5 and T11 (post-treatment dates), respectively. These values were log-transformed and compared using the Wilcoxon non-parametric test ( $\mathrm{R}$ package pgirmess).

The response of each phytoplankton taxonomical group to Bti treatment was analyzed using generalized linear mixed models (GLMM), with time and sites as fixed effects (due to the low number of sites; Bolker et al., 2009) and dates and replicates nested in dates as random effects. To account for overdispersed count-data, we used negative binomial distribution as error distribution using the $\mathrm{R}$ software (version 3.1.2, R Core Team 2013) and the
glmmADMB package (Fournier et al., 2012). These GLMMs estimated the average responses of phytoplankton abundance to $B t i$ treatment over time, the betweendates variability of these responses and the variability among replicates.

Dissimilarity of phytoplankton communities was assessed using the Bray-Curtis distance calculation based on phytoplankton species cell counts. Between pseudoreplicates dissimilarities were calculated for each campaign and each date. Between-dates distances were calculated between $\mathrm{T} 0$ and $\mathrm{T} 2, \mathrm{~T} 0$ and $\mathrm{T} 5, \mathrm{~T} 0$ and $\mathrm{T} 11$, for each campaign. Between-sites differences were estimated for campaigns performed during the same season and for the same dates (T0, T2, T5 and T11). Finally, between-years changes were calculated between 2 years, respectively, 1,2 , 3 or 4 years of treatment apart.

Shannon's entropy and Pielou's evenness indices were calculated for the control (date T0) and after VectoBac ${ }^{\mathbb{R}}$ applications (mean values of post-treatment dates T2, T5 and T11). The calculations were performed with the $\mathrm{R}$ package Vegan, and were compared using the Wilcoxon non-parametric test ( $\mathrm{R}$ package pgirmess).

\section{Results}

\section{Water quality and nutrients}

Water temperature varied from 9.4 to $25.9^{\circ} \mathrm{C}$ (February-July) and the mean depth of these sites never exceeded $56 \mathrm{~cm}$ (Table 2). Salinity varied slightly according to the source of flooding and the impact of the salt ground water during the decrease in water level (Table 2).

Chemical parameter values indicate the very limited effect of nutritive enrichment in the three study sites: nitrite $\left(\mathrm{N}-\mathrm{NO}^{-2}\right)$, nitrate $\left(\mathrm{N}-\mathrm{NO}^{-3}\right)$ and $\mathrm{SRP}$ values were very low, never exceeding $0.01 \mathrm{mg} . \mathrm{L}^{-1}, 0.1 \mathrm{mg} . \mathrm{L}^{-1}$ and 0.04 g. $\mathrm{L}^{-1}$, respectively. Nutrient values indicated oligotrophic conditions at all three study sites.

\section{Phytoplankton communities}

\section{Total density}

At sites 1 and 2, between-campaigns changes were observed in all total phytoplankton densities (Fig. 1(a) and (b). At site 1, total densities were similar in 2008 and 

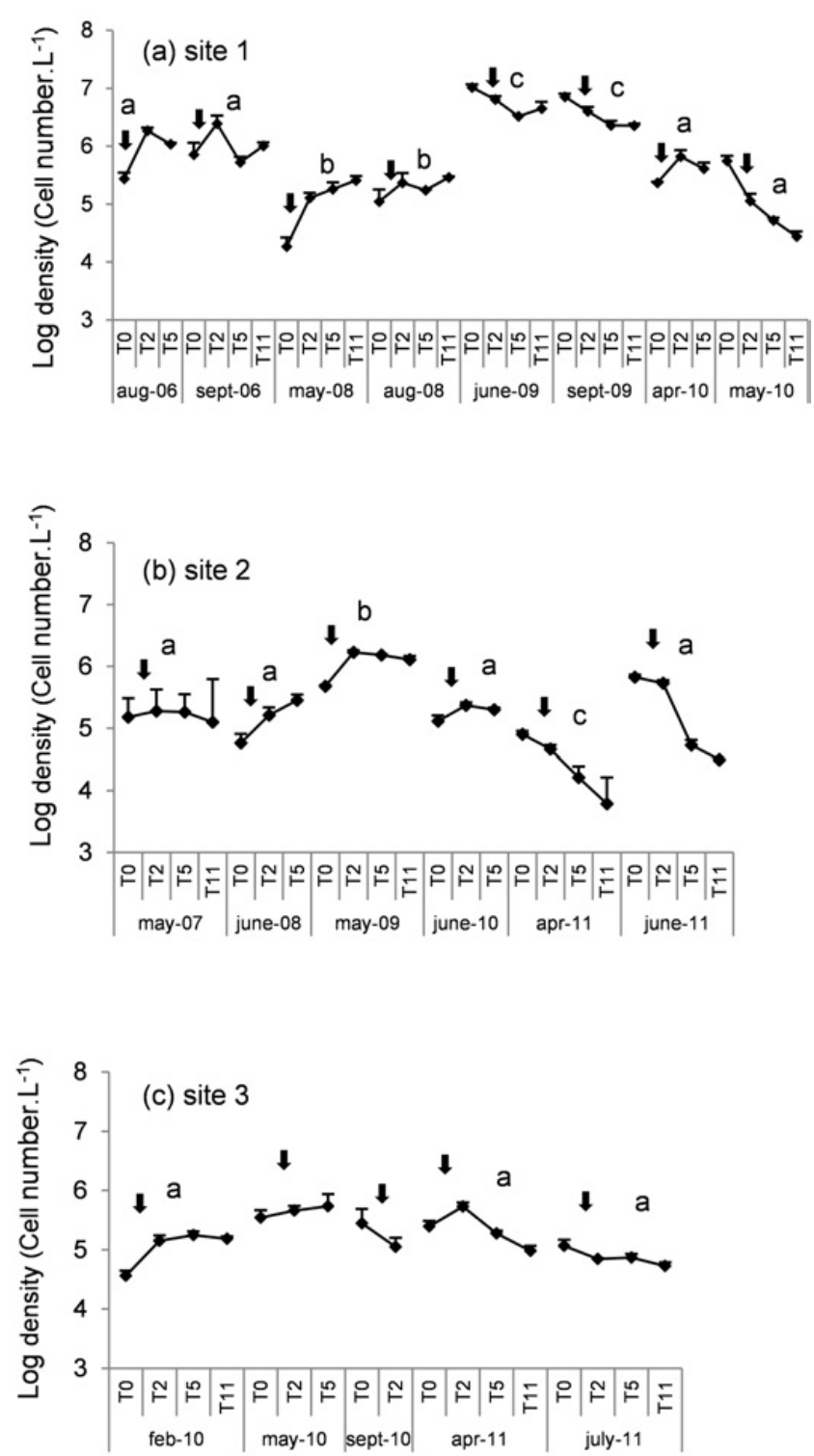

Fig. 1. Changes in mean $\pm \mathrm{SE}(n=3)$ phytoplankton cell density (cell.L ${ }^{-1}$, Log-transformed) at site 1 (a), site 2 (b) and site 3 (c) in the control (date T0) and after VectoBac ${ }^{\mathbb{R}}$ application (T2, T5 and T11, post-treatment dates). Different letters indicate significant differences according to Wilcoxon test $(P<0.05)$. Small arrows indicate the VectoBac ${ }^{\circledR}$ applications (between T0 and $\mathrm{T} 2$ ) in the treated area. were significantly lower than densities registered in 2006, 2009 and 2010. These total densities were significantly higher for the two campaigns of 2009. At site 2, total phytoplankton densities were significantly higher in 2009 than in any other campaigns, and they were significantly lower in April 2011 than in any other campaigns. Algal cell densities at these two sites were highest in 2009. At site 3, a non-significant low temporal variation was observed between campaigns (Wilcoxon test, $P>0.05$ ).

The dynamics of total phytoplankton densities (between T0 and T11) differed from site to site and campaign to campaign. Density patterns varied widely with cases both of increase (12 cases as follows: site 1: August and September 2006, May and August 2008 and April 2010; site 2: May 2007, June 2008, May 2009, June 2010; site 3: February and May 2010 and April 2011) and of decrease (seven cases) between the control date (T0) and the first post-treatment date (T2). Nevertheless, between-dates comparison (T0/T2, T0/T5 and T0/T11 for a single site and a single campaign) revealed the differences to be nonsignificant (Wilcoxon test, $P$-value $>0.05$ ), Thus, no tendency to phytoplankton proliferation was observed. Despite this inter-annual variability, total phytoplankton densities did not increase systematically after Bti-treatment.

\section{Density of phytoplankton taxonomic groups}

Five phytoplankton taxonomic groups were identified: Bacillariophyta (Diatoms), Chlorophyta, Cyanobacteria, Euglenophyta and Dinophyta. The GLMM showed Diatoms to be the only group with a significant average decrease in density over time (Wald test, $P$-value $<0.001$ ). Diatoms group density showed a significant decrease after T0. No significant relationships between density and time were observed for the four other groups. The betweendates variability (random effect, Table 3 ) in the relationships between phytoplankton group density and times (intercept and slopes) was always significant (likelihood ratio test, $P$-value $<0.001)$. Notably, the between-dates variability on the slopes was always high (greater than the standard deviation on the fixed effect). No pattern emerged, since almost all possible responses of densities to time could be observed. In contrast, the variability

Table 3. Effect of time (fixed effect) on algae abundances (slope on the link scale), and between-dates and between-replicates variability on intercept and slopes (random effect, SD). The significant effects are in bold (Wald test for the fixed effect and likelihood ratio test for random effects, $\alpha=5 \%$ ).

\begin{tabular}{|c|c|c|c|c|c|c|}
\hline & & & \multicolumn{4}{|c|}{ Random effect } \\
\hline & \multicolumn{2}{|c|}{ Fixed effect } & \multicolumn{2}{|c|}{ Date } & \multicolumn{2}{|c|}{ Replicates } \\
\hline$\overline{\text { Diatoms }}$ & $7.5426(0.6662)$ & $-0.3061(0.0775)$ & 1.459 & 0.2961 & $7.8 \times 10^{-5}$ & $4.6 \times 10^{-5}$ \\
\hline Cyanobacteria & $9.5716(0.4096)$ & $-0.0288(0.0437)$ & 0.8533 & 0.1349 & $1.3 \times 10^{-4}$ & $5.3 \times 10^{-5}$ \\
\hline Euglenophyta & $6.4881(1.1538)$ & $-0.0145(0.0325)$ & 2.7579 & 0.0985 & & \\
\hline Dinophyta & $1.1515(2.3225)$ & $0.5078(0.3283)$ & 4.709 & 1.2814 & $2 \times 10^{-4}$ & $5.9 \times 10^{-5}$ \\
\hline
\end{tabular}



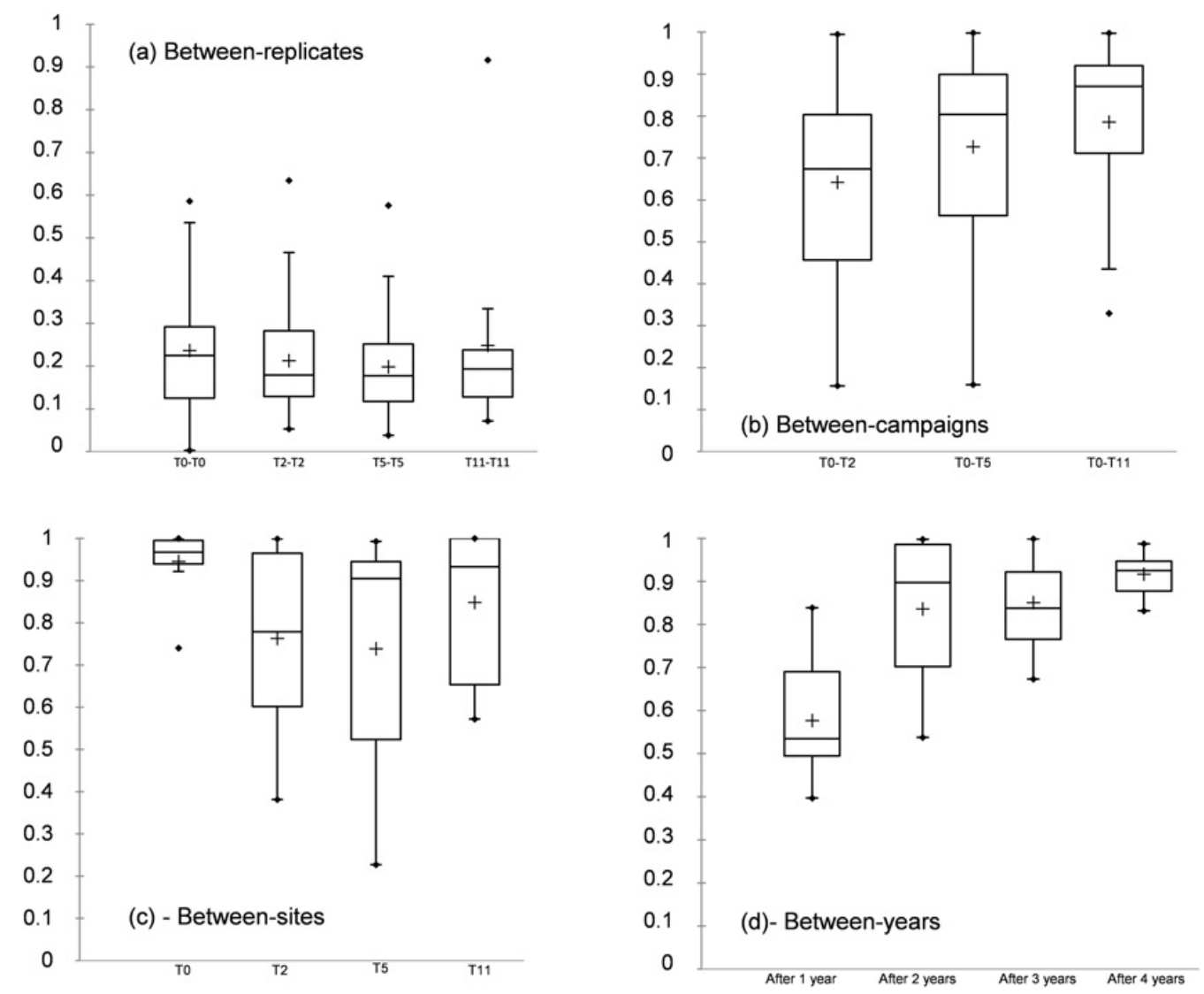

Fig. 2. Box plots for dissimilarity of phytoplankton communities (median, minimum-maximum values of Bray-Curtis distance). (a) Between pseudo-replicates distance calculated for each campaign and each date. (b) Between-dates distances calculated between T0 and T2, T0 and T5, T0 and T11, for each campaign. (c) Between-sites distances were estimated for the same dates (T0, T2, T5 and T11) and for campaigns performed in the same season. Between-years distances were calculated between 2 years, respectively, 1, 2, 3 or 4 years of treatment apart.

between replicates for a given date was very low, a thousand times lower than between dates (Table 3) and never significant (likelihood ratio test, $P$-value $>0.05$ ). For the Euglenophyta, this variability was even too low to be estimated.

\section{Phytoplankton community structure}

Between-pseudo-replicates dissimilarity was quite low, and did not change during a given campaign. The median varied between $17 \%$ (post-treatment T5) and $22.5 \%$ (control T0) (Fig. 2(a)), suggesting similar phytoplankton densities in the pseudo-replicates at all three sites. Between-dates dissimilarity values were quite high, and fluctuated during a given campaign (Fig. 2(b)). The median of the Bray-Curtis index varied between $67.4 \%$ (T0/T2) and 87.1\% (T0/T11). The highest values were usually observed when the wetland began to dry up, suggesting that the impact of drought may have been greater than that of the VectoBac ${ }^{\circledR}$ applications.

Between-sites dissimilarity (Fig. 2(c)) was very high, with the medians of the Bray-Curtis index varying between $77.9 \%$ (T2) and 96.7\% (T0 control), confirming the hypothesis of higher phytoplankton community variability linked to inputs of water and origin of irrigation, and thus random phytoplankton colonization. Moreover, between-years dissimilarity (Fig. 2(d)) was high, the median varying from $53.3 \%$ (after 1 year of treatment) up to more than $80 \%$ (after, 2, 3 and 4 years of treatment), suggesting that each new water input engendered a new algal colonization leading to increasing between-years differences in communities.

A total of 88 phytoplankton taxa were identified over 19 treatment campaigns. Diatoms dominated, with 47 taxa. Chlorophyta (green algae) were represented by 21 taxa, Euglenophyta by 14 taxa, Cyanobacteria by 13 taxa and Dinophyta by four taxa.

The Shannon diversity values measured at the three sites for 19 phytoplankton sampling campaigns (Fig. 3(a)) showed high variability between sampling campaigns. We noted a greater variability at T0 (control) for each phytoplankton sampling campaign than immediately after VectoBac ${ }^{\circledR}$ applications (post-treatment dates). At site 1, the highest Shannon diversity index value was observed at control T0 in April 2010 (IS = 3.37) and the lowest at control T0 in September $2009(\mathrm{~min}=0.042)$. At site 2, the highest Shannon diversity index value was observed at control T0 in June 2010 (IS = 3.33). In June 2008, only one 

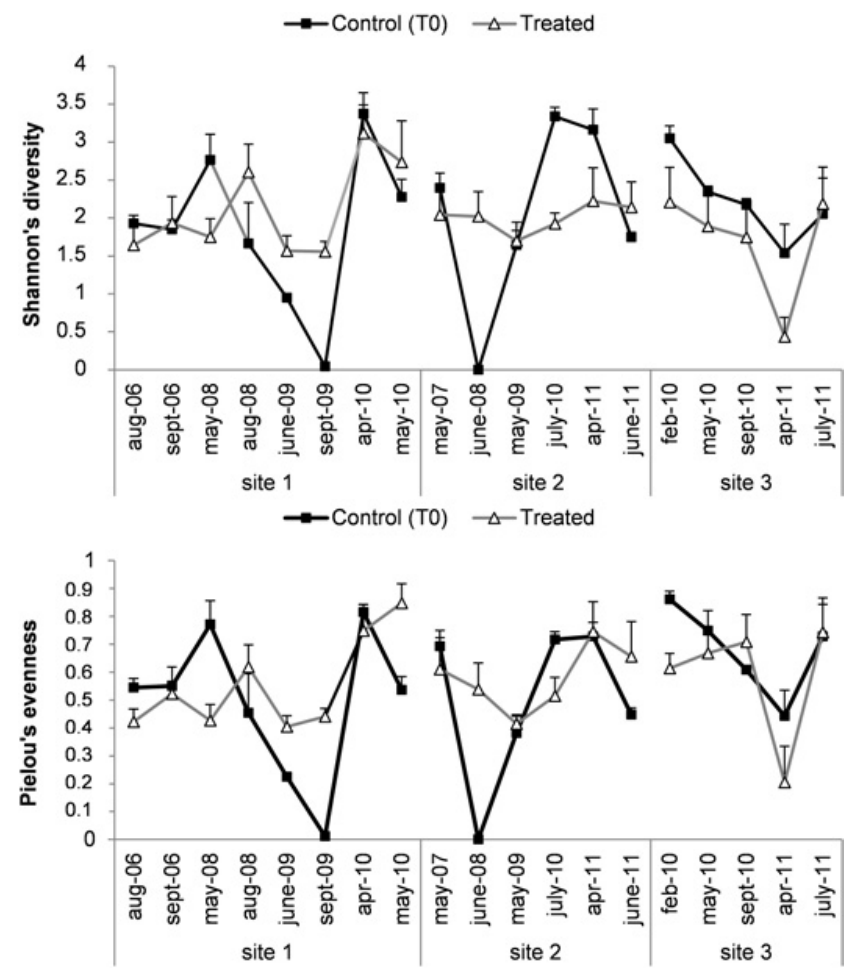

Fig. 3. Mean values \pm SE of Shannon's entropy index (a) and Pielou's evenness index (b) measured on the control (date T0, $n=3$ ) and post-treatment by VectoBac ${ }^{\mathbb{R}}$ dates (T2, T5 and T11, $n=9)$ at three sites and in 19 campaigns.

phytoplankton species was detected in samples, explaining the value of $\mathrm{IS}=0$. At site 3 , the highest value was measured at control T0 in February (IS = 3.04), and the lowest value was measured post-treatment (April 2011; IS $=0.44$ ). No significant differences in Shannon's diversity index appeared between control T0 and post-treatment dates for any site (Wilcoxon test, $P>0.5$ at the three sites). Pielou's evenness values (Fig. 3(b)) evolved in the same way at the three sites, and evenness index values were not statistically significant. Like phytoplankton densities, community structure descriptors showed large temporal variations, and did not systematically decrease after VectoBac ${ }^{\circledR}$ spraying. Actually, diversity and evenness varied widely, with cases of both increase and decrease, except for site 3 . These results indicate marked temporal changes in the three pools, without any real pattern.

\section{Discussion}

Phytoplankton may be ideal indicators in aquatic systems because of their ubiquitous distribution and rapid response to variable environmental stresses (Hutchinson, 1967; Lowe and Pan, 1996). Our findings indicate that phytoplankton community variability (total density, taxonomic group density and community structure) in treated wetlands of our study area is driven by natural fluctuations in the environmental conditions of each site. No trends towards phytoplankton proliferation or density increase were observed under VectoBac ${ }^{\circledR}$ spraying over a long term. The differences in phytoplankton densities observed can be explained by the inter-annual variability present in coastal wetlands (Goldsborough and Robinson, 1996; Goldsborough, 2001) and can be attributed to shifts in phytoplankton community dynamics. High variability in physico-chemical parameters and hydrological conditions, including temperature, salinity, water depth, inputs of water, drought and seasonality, influenced phytoplankton colonization in these wetlands. Previous field studies failed to demonstrate short- or long-term effects of $B t i$ on non-target species (Niemi et al., 1999; Duchet et al., 2008, 2010; Lündstrom et al., 2010a, 2010b; Caquet et al., 2011; Lagadic et al., 2014), reaching the same conclusions. Hydrological patterns play an important role in site heterogeneity in the Camargue wetlands. Phytoplankton dynamics are influenced by the duration of the hydroperiod and by seasonality in temporary wetlands, especially in a Mediterranean climate (Nuccio et al., 2003). Flooding and areal inundation were also shown to be decisive for annual heterogeneity of phytoplankton densities, with wetland landscape heterogeneity conditioned by water inflows due to areal inundation (Angeler et al., 2000).

In the Camargue wetland sites treated here, no phytoplankton proliferation was observed after the disappearance of mosquito larvae. Earlier research showed that a high-dosage Bti-treatment induced a significant reduction of algal biomass (proxied by total chlorophyll a) 2 weeks after Bti application (Su and Mulla, 1999; Duguma, 2013). Duguma (2013) monitored the algal biomass and showed that it ceased growing 9 days after strong Bti application. The high-dosage Bti treatments in Duguma (2013), Duguma et al. (2015), and in Su and Mulla (1999) were however significantly higher than that advised within the framework of mosquito control in our wetlands. Their findings revealed that the decrease in algal biomass noticed in the water column was not necessarily attributable to the chemical composition and application of VectoBac G. An alternative hypothesis is that application of Bti may have had an indirect effect mediated by the bacterial communities. Some research evidenced speciesspecific interactions between bacteria and phytoplankton, and concluded that bacteria contribute to the control of phytoplankton dynamics. Mayali and Azam (2004) suggested that bacterial-algal interactions (e.g., symbiosis, commensalisms) can shift to competition under stress conditions, and result to lysis and even cell death of algae by algicidal bacteria. According to Duguma (2013), Bti treatments may increase bacterial colonization and induce greater biochemical activities such as excretion of algicides (e.g., antibiotics). Several bacteria (genus Bacillus) specialized in antibiotics secretion and algicidal activities are known to cause the inhibition of Cyanobacterial growth (Reim et al., 1974).

In our study, the dominant phytoplankton taxonomic group is inoculated naturally by water input to wetland areas, and is composed of Diatoms and Cyanobacteria. During flooding by irrigation or precipitation, this Diatom inoculum is made of colonizer species ( $r$-strategies) rather 
than a competitor species. Here, the Diatom group tended to decrease, being replaced by species more typical of temporary wetlands such as Euglenophyta and Dinophyta, whereas the Cyanobacteria remained. Temporary pools do not provide very suitable ecological niches for Diatoms, particularly in view of the hydrological fluctuations characteristic of such pools. In these temporary pools, therefore, the Diatom group did not constitute a suitable bioindicator for monitoring the effects of Bti treatment: decreasing depth and the subsequent drought events contributed to their decline. Another possible explanation for the decrease in Diatoms may be low inorganic nutrient levels that they were eliminated by other inorganics located very low in these wetlands, such as silicium (Dixit et al., 1992). An important question is whether Bti treatment may be the cause. According to Goldsborough (2001) the short generation time of algal cells means that changes in taxonomic composition of an assemblage, due to toxicant exposure for instance, can occur within a few days. Thus, changes in the proportions of phytoplankton taxonomic group, or local extinction, may be sensitive indicators of autogenic or allogenic stress. This hypothesis of a direct effect of Bti treatment on the Diatoms group needs to be tested within the framework of a study in batch culture. Laboratory bioassays should be conducted with a limited number of cultivable Diatom species. According to Koskella and Stotzky (2002), the insecticidal toxins from $B t i$ did not affect the growth of a variety of algae (primarily green and Diatoms) in pure and mixed culture. The toxins from $B t i$ were also non-inhibitory in dilution tests to pure and mixed cultures of algae and Cyanobacteria. Although the results of these in vitro studies agree with those observed in studies in soil, none of these studies evaluated changes in the composition of mixed cultures. The authors concluded that further studies on the effects of these toxins on biodiversity are clearly needed.

These hypotheses of allogenic stress and direct effect linked to Bti application are not consistent with our observations. Indeed, before Bti treatment (control T0), the density of phytoplankton taxonomical groups varied widely due to the coexistence of two phytoplankton communities, the exogenous community dominated by Diatoms and Cyanobacteria inoculated by inputs of water, and the endogenous community at each site represented by an algal crust (Euglenophyta, Dinophyta). The Diatom group responds rapidly to environmental conditions, so drought events may limit development of some species. The temporal dynamics of the phytoplankton groups between $\mathrm{T} 0$ and $\mathrm{T} 2$, $\mathrm{T} 5$ and $\mathrm{T} 11$ in these temporary wetlands can be described by the following colonization dynamics. At T0: flooding (by irrigation or precipitation) leads to a phytoplankton community composed of "exogenous" algal and cyanobacteria groups represented and dominated by Diatoms (colonizers) and Cyanobacteria (competitors). Water input engenders the detachment of the algal community composed of "endogenous" algal groups, plocon and metaphyton, as described by Goldsborough (2001) in his work on phytoplankton assemblages in wetlands. The detached algae plocon and metaphyton are typical of encysted Euglenophyta, Chlorophyta and Dinophyta. Chlorophyta can be considered as competitors but this algal group is weakly represented because calcareous conditions are more marked and nutrient input lower. At dates T2 and $\mathrm{T} 5$, fast-growing algae enhanced by water input and the detachment of the algal crust increase, and recolonize the water column. Cyanobacteria and Euglenophyta identified in temporary wetlands possess wide ecological valency, with a tolerance for drought expressed by forming an algal crust and desiccation as well as fast recolonization (2 days). At T11, evidence of the decrease in water depth and inundation area is provided by the algal crust formed at the surface, usually composed of mucilaginous cyanobacterial trichomes, including motile Euglenophyta cysts. Euglenophyta and Cyanobacteria are common in these Mediterranean temporary wetlands, due to their ability to tolerate variations in water level and desiccation.

The changes in the density of phytoplankton taxonomical groups observed here are therefore due to natural conditions related to alternating flooding and drought events, as phytoplankton responds to hydric stress. Phytoplankton subjected to a variable moisture regime must adapt, in order to tolerate extreme conditions (Sheath and Wher, 2003). Other filamentous forms (Oscillatoria, Nostoc) may, during the open (flooded) state, form thick mats that protect algal cells during a later dry phase (Sheath and Wher, 2003). In the Everglades wetlands, filamentous cyanobacteria, including Scytonema, Schizothrix, Oscillatoria and Microcoleus, are often abundant (Goldsborough and Robinson, 1996; Pan and Stevenson, 1996). In our temporary wetlands, the dynamics of the phytoplankton taxonomical groups changed over time, from the beginning of water input to water depletion in the pools, despite the very low nutrient input. Phosphorus limitation has been suggested as a factor structuring the taxonomic composition of phytoplankton communities in these wetlands (Beaver et al., 1998). Diversity measured by the Shannon index confirmed our conclusions on phytoplankton densities, i.e., there was no evidence of change for all descriptors of phytoplankton community structure after VectoBac ${ }^{\circledR}$ application. Although changes in the abundance of phytoplankton groups appeared during the monitoring of Bti-treatment, phytoplankton community structure was not impacted and the proportions of the different communities of the temporary wetlands remained the same after Bti-treatment.

\section{Conclusion}

The reduction of mosquito larval density ( $>80 \%$ ) by $B t i$ treatment did not indirectly affect the overall phytoplankton density and community structure in our treated 
temporary wetlands. Their elimination did not generate phytoplankton proliferation. It should be noted that the observed changes in phytoplankton taxonomic groups were due to natural conditions related to alternating flooding and drought events. We can thus conclude that the phytoplankton community was not under top-down control in our study systems. After investigating the indirect effects of Bti treatment we are able to confirm the hypothesis that this bioinsecticide does not affect phytoplankton density and diversity and does not constitute an anthropogenic stress to phytoplankton community.

Acknowledgements. Financial support for this work was provided by the Parc Naturel Régional de Camargue. We thank the technical coordinators of this project for making this study possible and EID-Mediterranée for providing details on Bti treatments, as well as Marjorie Sweetko for English language revision.

\section{References}

Angeler D.G., Alvarez-Cobelas M., Rojo C. and Sànchez-Carillo S., 2000. The significance of water inputs to plankton biomass and trophic relationships in a semi-arid freshwater wetland (central Spain). J. Plankton Res., 22, 2075-2093.

APHA, 1989. Standard Methods for the Examination of Water and Wastewater (17th edn), American Public Health Association, Washington, DC, $1268 \mathrm{p}$.

Beaver J.R., Miller-Lemke A.M. and Acton J.K., 1998. Midsummer zooplankton assemblages in four types of wetlands in the Upper Midwest, USA. Hydrobiol., 380, 209-220.

Becker, N., 2006. Microbial control of mosquitoes: management of the Upper Rhine mosquito population as a model programme. In: Eilenberg J. and Hokkanen H.M.T. (eds.), An Ecological and Societal Approach to Biological Control, Springer Verlag, Berlin, 227-245.

Becker N., Petric D., Zgomba M., Boase C., Dahl C., Lane J. and Kaiser A., 2003. Mosquitoes and Their Control, Kluwer Academic/Plenum Publishers, New York, 345-375.

Boisvert M. and Boisvert J., 2000. Effects of Bacillus thuringiensis var. israelensis on target and nontarget organisms: a review of laboratory and field experiments. Biocontrol Sci. Technol., $10,517-561$.

Bolker B.M., Brooks M.E., Clark C.J., Geange S.W., Poulsen J.R., Stevens M.H.H. and White J.-S.S., 2009. Generalized linear mixed models: a practical guide for ecology and evolution. Trends Ecol. Evol., 24, $127-135$.

Caquet T., Roucaute M., Le Goff P. and Lagadic L., 2011. Effects of repeated field applications of two formulations of Bacillus thuringiensis var. israelensis on non-target saltmarsh invertebrates in Atlantic coastal wetlands. Ecotox. Environ. Safe., 74, 1122-1130.

Despres L., Lagneau C. and Frutos R., 2011. Using the bioinsecticide Bacillus thuringiensis israelensis in mosquito control. In: Stoytcheva M. (ed.), Pesticides in the Modern World - Pests Control and Pesticides Exposure and Toxicity Assessment, InTech, Rijeka, Croatia, 93-126.

Dixit A.S., Dixit S.S. and Smol J.P., 1992. Long-term trends in lake water $\mathrm{pH}$ and metal concentrations inferred from diatoms and chrysophytes in three lakes near Sudbury, Ontario. Can. J. Fish. Aquat. Sci., 49, 17-24.

Duchet C., Larroque M., Caquet T., Franquet E., Lagneau C. and Lagadic L., 2008. Effects of spinosad and Bacillus thuringiensis israelensis on a natural population of Daphnia pulex in field microcosms. Chemosphere, 74, 70-77.

Duchet C., Caquet Th., Franquet E., Lagneau C. and Lagadic L., 2010. Influence of environmental factors on the response of a natural population of Daphnia magna (Crustacea: Cladocera) to spinosad and Bacillus thuringiensis israelensis in Mediterranean coastal wetlands. Environ. Pollut., 15, 1825-1833.

Duguma D.D., 2013. Influence of nutrients and integrated mosquito management tactics on mosquitoes and their habitat microbiomes. PhD thesis, University of California, Riverside, 169 p.

Duguma D.D., Hall M.W., Rugman-Jones P., Stouthamer R., Neufeld J.D. and Walton W.E., 2015. Microbial communities and nutrient dynamics in experimental microcosms are altered after the application of a high dose of Bti. J. Appl. Ecol., 52, 763-773.

Fournier D.A., Skaug H.J., Ancheta J., Ianelli J., Magnusson A., Maunder M., Nielsen A. and Sibert J., 2012. AD Model Builder: using automatic differentiation for statistical inference of highly parameterized complex nonlinear models. Optim. Methods Softw., 27, 233-249.

Goldsborough L.G., 2001. Sampling algae in wetlands. In: Russell B.R., Batzer D.P. and Wissinger S.A. (eds.), Bioassessment and Management of North American Freshwater Wetlands, John Wiley and sons, New York, 263-295.

Goldsborough L.G. and Robinson G.G.C., 1996. Pattern in wetlands. In: Stevenson R.J., Bothwell M.L. and Lowe R.L. (eds.), Algal Ecology: Freshwater Benthic Ecosystems, Academic Press, San Diego, 77-117.

Hagen K.H., 2009. Algae, Nutrition, Pollution Control and Energy Sources, New Science Publishers Inc., New York, 265-300.

Hershey A.E., Lima A.R., Niemi G.J. and Regal R.R., 1998. Effects of Bacillus thuringiensis israelensis (Bti) and methoprene on nontarget macroinvertebrates in Minesota wetlands. Ecol. Appl., 8, 41-60.

Hutchinson G.E., 1967. A Treatise on Limnology, II. Introduction to Lake Biology and the Limnoplankton, Wiley, New York, 1115 p.

Kirkman L.K., Whitehead E.A., Golladay S.W., Smith L.L. and Opsahl S.P., 2011. A research framework for identifying potential linkages between isolated wetlands and disease ecology. Ecol. Res., 26, 875-883.

Komàrek J. and Anagnostidis K., 1999. Süsswasserflora von Mitteleuropa. Band 19/1. Cyanoprokaryota 1. Teil: Chroococcales, Spektrum Akademischer Verlag, Heidelberg, Berlin, 548 p.

Komàrek J. and Anagnostidis K., 2005. Süsswasserflora von Mitteleuropa. Band 19/2. Cyanoprokaryota 1. Teil: Oscillatoriales, Elsevier-Spektrum Akademischer Verlag, Heidelberg, Munich, 759 p. 
Koskella J. and Stotzky G., 2002. Larvicidal toxins from Bacillus thuringiensis subspp. kurstaki, morrisoni (strain tenebrionis), and israelensis have no microbicidal or microbiostatic activity against selected bacteria, fungi, and algae in vitro. Can. J. Microbiol., 48, 262-267.

Krammer K. and Lange-Bertalot H., 1986. Bacillariophyceae 1. Teil, Naviculaceae. In: Ettl H., Gerloff J., Heynig H. and Mollenauseer D. (eds.), Süsswasserflora von Mitteleuropa. Band 2/1, Gustav Fisher Verlag, Stuttgart, 876 p.

Krammer L. and Lange-Bertalot H., 1988. Bacillariophyceae, 2: Teil, Bacillariaceae, Epithemiaceae, Surirellaceae. In: Ettl H., Gerloff J., Heynig H. and Mollenauseer D. (eds.), Süsswasserflora von Mitteleuropa. Band 2/2, Gustav Fisher Verlag, Stuttgart, 596 p.

Krammer L. and Lange-Bertalot H., 1991a. Bacillariophyceae, 3: Teil, Centrales, Fragilariaceae, Eunotiaceae. In: Ettl H., Gerloff J., Heynig H. and Mollenauseer D. (eds.), Süsswasserflora von Mitteleuropa. Band 2/3, Gustav Fisher Verlag Publishers, Stuttgart, 576 p.

Krammer L. and Lange-Bertalot H., 1991b. Bacillariophyceae, 4: Teil, Achnanthaceae: Kritische Erganzungen zu Navicula (Lineolatae) und Gomphonema Gesamtliteraturverzeichnis. In: Ettl H., Gerloff J., Heynig H. and Mollenauseer D. (eds.), Süsswasserflora von Mitteleuropa. Band 2/4, G. Fisher Verlag, Stuttgart, 437 p.

Lacey L.A. and Merritt D.L., 2004. The safety of bacterial microbial agents used for black fly and mosquito control in aquatic environments. In: Hokkanen H.M.T. and Hajek A.E. (eds.), Environmental Impacts of Microbial Insecticides: Need and Methods for Risk Assessment, Kluwer Academic Publishers, Dordrecht, 151-168.

Lacoursière J.O. and Boisvert J., 2004. Le Bacillus thuringiensis et le contrôle des insectes piqueurs au Québec, ENV/2004/ 0278, Ministère de l'Environnement Québequois, Québec, $101 \mathrm{p}$.

Lagadic L., Caquet T., Fourcy D. and Heydorff, M., 2002. Évaluation à long terme des effets de la démoustication dans le Morbihan. Suivi de l'impact écotoxicologique des traitements sur les invertébrés aquatiques entre 1998 et 2001. Scientific Report. April 2002, Research Agreement Conseil Général du Morbihan, 215 p.

Lagadic L., Roucaute M. and Caquet T., 2014. Bti sprays do not adversely affect non-target aquatic invertebrates in French Atlantic coastal wetlands. J. Appl. Ecol., 51, 102-113.

Lowe R.L. and Pan Y., 1996. Benthic algal communities as biological indicators. In: Stevenson R.J., Bothwell M.L. and Lowe R.L. (eds.), Algal Ecology: Freshwater Benthic Ecosystems, Academic Press, 753 p.

Lundström J.O., Brodin Y., Schäfer M.L., Vinnersten T.Z.P. and Östman Ö., 2010a. High species richness of Chironomidae (Diptera) in temporary flooded wetlands associated with high species turn-over rates. Bull. Entomol. Res., 100, 433-444.

Lundström J.O., Schäfer M.L., Petersson E., Vinnersten T.Z.P., Landin J. and Brodin Y., 2010b. Production of wetlands Chironomidae (Diptera) and the effects of using Bacillus thuringiensis israelensis for mosquito control. Bull. Entomol. Res., 100, 117-125.

Mainstone C.P. and Parr W., 2002. Phosphorus in rivers-ecology and management. Sci. Total Environ., 282-283, 25-47.

Marten G.G., 2007. Larvicidal algae. Am. Mosq. Control Assoc. Bull., 7, 177-183.
Mayali X. and Azam F., 2004. Algicidal Bacteria in the Sea and their Impact on Algal Blooms. Eukaryot. Microbiol., 51(2), 139-144.

Merritt R.W., Dadd R.H. and Walker E.D., 1992. Feeding behavior, natural food and nutritional relationships of larval mosquitoes. Annu. Rev. Entomol., 37, 349-376.

Niemi G.J., Hershey A.E., Shannon L., Hanowski J.M., Lima A., Axler R.P. and Regal R.R., 1999. Ecological effects of mosquito control on zooplankton, insects and birds. Environ. Toxicol. Chem., 18, 549-559.

Nuccio C., Melillo C., Massia L. and Innamorati M., 2003. Phytoplankton abundance, community structure and diversity in the eutrophic Orbetello lagoon (Tuscany) from 1995 to 2001. Oceanol. Acta, 26, 15-25.

OECD, 1982. Eutrophication of Waters. Monitoring, Assessment and Control. Organisation for Economic Cooperation and Development, (Publié en français sous le titre "Eutrophication des Eaux. Méthodes de Surveillance, d'Evaluation et de Lutte"), Paris, 154 p.

Östman Ö., Lundström J.O. and Vinnersten T.Z.P., 2008. Effects of mosquito larvae removal with Bacillus thuringiensis israelensis (Bti) on natural protozoan communities. Hydrobiology, 607, 231-235.

Pan Y. and Stevenson R.J., 1996. Gradient analysis of diatom communities in western Kentucky wetlands. J. Phycol., 32, 222-232.

Poulin B., Lefebvre G. and Paz L., 2010. Red flag for green spray: adverse trophic effects of Bti on breeding birds. J. Appl. Ecol., 47, 884-889.

$\mathrm{R}$ Core Team, 2013. R: A language and environment for statistical computing, R Foundation for Statistical Computing, Vienna, Austria. ISBN 3-900051-07-0, http://www. R-project.org/.

Reavie E.D., Smol J.P. and Carmichael N.B., 1995. Postsettlement eutrophication histories of six British Columbia (Canada) lakes. Can. J. Fish. Aquat. Sci., 52, 2388-2401.

Reim R.L., Shane M.S. and Cannon R.E., 1974. The characterization of a Bacillus capable of blue-green bactericidal activity. Can. J. Microbiol., 20, 981-986.

Robinson G.G.C., Gurney S.E. and Goldsborough L.G., 1997. The primary productivity of benthic and planktonic algae in a prairie wetland under controlled water-level regimes. Wetlands, 17, 182-194.

Russell R.C., 1999. Constructed wetlands and mosquitoes: health hazards and management options - an Australian perspective. Ecol. Eng., 12, 107-124.

Russell T.L., Kay B.H. and Skilleter G.A., 2009. Environmental effects of mosquito insecticides on saltmarsh invertebrate fauna. Aquat. Biol., 6, 77-90.

Sheath R.G. and Wehr J.D., 2003. Introduction to freshwater algae. In: Wehr J.D. and Sheath R.G. (eds.), Freshwater Algae of North America: Ecology and Classification, Academic Press, San Diego, 1-9.

$\mathrm{Su}$ T. and Mulla M.S., 1999. Microbial agents Bacillus thuringiensis ssp. israelensis and Bacillus sphaericus suppress eutrophication, enhance water quality, and control mosquitoes in microcosms. Environ. Entomol., 28, 761-767.

Walton W.E., 2002. Multipurpose constructed treatment wetlands in the arid southwestern United States: are the benefits worth the risks. In: Pries J. (ed.), Proceedings of the 
Conference "Treatment Wetlands for Water Quality Improvement: Quebec 2000", (Selected Papers), CH2M Hill Canada Limited, Pandora Press, Waterloo, Ontario, Canada, 115-123.

Wegner E., 2006. Mosquito control programme implemented in Wilanów (Warsaw, Poland) in summer 2002. Eur. Mosq. Bull., 21, 14-18.

Weilhoefer C.L. and Pan Y., 2007. Relationships between diatoms and environmental variables in wetlands in the Willamette valley. Oregon, USA. Wetlands, 27, 668-682.
Wotowski K. and Hindàk F., 2005. Atlas of Euglenophytes. House of the Slovak Academy of Sciences VEDA/ Publishing, Bratislava, $136 \mathrm{p}$.

Wu X. and Mitsch W.J., 1998. Spatial and temporal patterns of algae in newly constructed freshwater wetlands. Wetlands, $18,9-20$.

$\mathrm{Xu}$ Y., Chen S., Kaufman M.G., Maknojia S. and Bagdsarian M., 2008. Bacterial community structure in tree hole habitats of Ochlerotatus triseiatus: influences of larval feeding. J. Am. Mosq. Control Assoc., 24, 219-227. 